\title{
BOEKBESPREKING
}

\section{The gang game: the myth and seduction of gangs}

\author{
Luuk Slooter
}

Hellemont, E. Van (2015). The gang game: the myth and seduction of gangs (dissertatie Universiteit Leuven, Doctoral School Humanities and Social Sciences).

Waarom hebben gangs op jongeren een fatale - zelfs obsessief dodelijke - aantrekkingskracht? Het is de eerste zin en meteen ook de hoofdvraag die Elke Van Hellemont poogt te beantwoorden in haar proefschrift The gang game: the myth and seduction of gangs. Haar studie naar Congolese gangs in Brussel is echter omvangrijker en ambitieuzer dan die openingszin doet vermoeden. In negen hoofdstukken en op basis van een duizelingwekkende hoeveelheid kwantitatieve en kwalitatieve data leidt Van Hellemont de lezer vakkundig door de wereld van Brusselse gangs. Een wereld die zich openbaart vanaf de jaren negentig in de nasleep van de Amerikaanse film New Jack City en sindsdien aan politieke en maatschappelijke urgentie heeft gewonnen. Een wereld die inzoomt op bepaalde groepen (gangs als 1140 en Versailles) en kristalliseert op bepaalde plekken in de stad (Evere en Elsene, en in het bijzonder de Afrikaanse wijk Matongé en rondom Naamsepoort). Maar vooral een wereld die zich in het schaduwgebied bevindt tussen fictie en realiteit.

In de zoektocht naar de aantrekkingskracht van gangs stelt Van Hellemont dat ze eerst twee diepere, onderliggende vragen dient te beantwoorden: wat zijn 'gangs' en hoe worden ze gevormd? Uiteindelijk krijgen deze twee vragen, meer dan de hoofdvraag, de meeste aandacht in het proefschrift. Van Hellemont stelt, in navolging van Katz en Jackson-Jacobs (2004), dat gangs gezien moeten worden als 'mythes': vertekende of vervormde interpretaties van de realiteit. De constructie en de continuering van die mythes beschrijft Van Hellemont als een spel waarin verschillende spelers deelnemen: jonge Congolese mannen op straat, politieagenten, beleidsmedewerkers, journalisten, politici en het grotere Belgische publiek. Het proefschrift brengt in kaart hoe het spel gespeeld wordt en waarom het zo verleidelijk en aantrekkelijk is om eraan mee te doen.

In het eerste deel wordt het theoretische en conceptuele fundament gelegd voor The gang game. Op basis van een uiteenzetting van positivistisch en constructivistisch onderzoek naar gangs en geïnspireerd door het klassieke werk van Thrasher (1927) en Katz (1988) definieert Van Hellemont haar eigen aanpak. Ze presenteert niet zozeer een nieuwe theorie, maar bepleit een verschuiving van de focus in gangonderzoek. Drie punten staan daarin centraal. Ten eerste stelt ze voor om niet, zoals gebruikelijk, een 'criminele' of 'informele sociale groep' als basis voor gangs te zien, maar een zogenoemde 'play group'. Die term, zo stelt ze in navolging van Thrasher, onderstreept het spontane, creatieve en collectieve karakter van het ontstaan van gangs. Ten tweede bepleit Van Hellemont dat gangonderzoekers 
zich minder uitsluitend moeten richten op crimineel gedrag, en meer zouden moeten kijken naar 'mythmaking practices', een bredere set van 'narratives' en 'performances' die vormend zijn voor gangs. En tot slot beargumenteert ze dat onderzoek niet alleen moet inzoomen op het 'lokale' (de wijk waarin de gang actief is), maar ook op het 'globale' (met name de impact van wereldwijde verspreiding van stereotiepe beelden van gangs door massamedia, in films, rapclips en fictie).

In de daaropvolgende hoofdstukken beschrijft Van Hellemont haar methodologische aanpak en introduceert ze de casus die centraal staat in haar onderzoek. Het proefschrift is voornamelijk gebaseerd op achttien maanden etnografisch onderzoek, zowel op straat onder Congolese jonge mannen als in de beleidswereld: ze is betrokken bij een gang-preventieproject, kijkt mee met de openbaar aanklager en interviewt politieagenten. Daarnaast houdt Van Hellemont een survey onder 1.139 jongeren, analyseert ze berichtgeving over gangs in zes Belgische kranten en bestudeert ze 38 rapsongs, 170 weblogs en een reeks beleidsdocumenten. Naast een beschrijving van deze imposante reeks van dataverzamelingstechnieken, presenteert ze vooral een open en eerlijk verhaal over de hobbelige en rommelige weg van het doen van onderzoek. Een weg getekend door tegenslagen en fouten, emoties en ethische dilemma's. Een verhaal over hoe ze ongewild verstrengeld raakte in politieke en beleidsmatige processen, over de voor- en nadelen van de ervaren tegenstellingen tussen haarzelf als witte, Belgische, Nederlandstalige, welvarende vrouw en de zwarte, Congolese, Franstalige, arme jonge mannen die ze onderzoekt. Een van haar begeleiders gaf haar het advies om zich aan het begin van haar veldwerk kwetsbaar op te stellen, om zo makkelijker toegang te krijgen tot haar respondenten. Die kwetsbaarheid tekent in feite ook het derde hoofdstuk. Ze vraagt zich openlijk af of ze niet te nauw betrokken is geraakt bij haar respondenten. Ze laat het oordeel over aan de lezer. De rijke illustraties en vignetten door het gehele proefschrift heen zijn in ieder geval het bewijs dat het haar buitengewoon goed gelukt is om diep door te dringen tot verschillende werelden, zowel die van de straat (Congolese jonge mannen) als die van de staat (beleidsmedewerkers, politieagenten, openbaar aanklager). Dat is prijzenswaardig. Opvallend is daarbij wel dat de vele vignetten waarin haar respondenten een stem krijgen uitsluitend in het Frans zijn weergegeven, in een verder Engelstalig proefschrift. Zonder kennis van het Frans zal de lezer dus een belangrijk en kleurrijk deel van dit proefschrift missen.

In de tweede helft van het proefschrift, hoofdstuk $5 \mathrm{t} / \mathrm{m} \mathrm{9}$, worden de belangrijkste spelers in de gang game besproken. Hoofdstuk 5 en 6 laten zien hoe jongeren op straat het spel spelen, de mythe creëren en in stand houden. Hoe realiteit vermengd wordt met fictieve elementen uit films en gangsta-rap, hoe je naam maakt in de gang, welke rollen je moet spelen en hoe je status krijgt, zowel online op blogs als offline op straat. Van cruciaal belang is daarbij, volgens Van Hellemont, de interpretatie van het publiek: komen verhalen (narratives) en handelingen (performances), zowel op individueel als op groepsniveau, authentiek en geloofwaardig over? Worden de legende en reputatie van de gang omarmd door het publiek? Episodes van geweld en vooral ook de opgeklopte verhalen daarover kunnen bij uitstek de status en geloofwaardigheid als gangster verhogen. Tegelijkertijd, zo beargumenteert Van Hellemont, komt een groot deel van (de dreiging van) 
geweld en wapenbezit niet zozeer voort uit de drang naar status en eer, maar vooral uit angst om zelf slachtoffer van geweld te worden.

Hoofdstuk 7 en 8 gaan over de andere belangrijke spelers in het spel, over hoe beleidsmedewerkers en journalisten bijdragen aan de vorming, continuering en institutionalisering van gangmythes. Van Hellemont claimt dat er onder beleidsmakers (net als onder wetenschappers) geen eenduidige definitie van de gang bestaat. Een gebrek aan kennis, maar ook politieke en pragmatische redenen leiden ertoe dat het etiket 'gang' of 'gangmember' voornamelijk wordt opgeplakt op basis van persoonlijke oordelen. Het gangprobleem in Brussel wordt zo uitvergroot en krijgt een fictief karakter, in sommige gevallen bewust om extra aandacht of subsidies te genereren. Daarnaast bestudeert Van Hellemont de mediaberichtgeving over twee fatale steekincidenten (in 2008 en 2010). Ze laat zien dat in de berichtgeving verschillende verhalen ontstaan over wat er gebeurd is, wie er betrokken waren en door welke motieven de steekpartijen werden gedreven. Ze stelt dat mediaberichtgeving versimpeld en aantrekkelijker gemaakt wordt door het gebruik van 'West Side Story stereotypes' en sensationele termen als 'slachtpartijen', 'bendeoorlogen' en 'gang vendettas' en laat zien hoe de twee individuele incidenten gemakkelijk gegeneraliseerd worden naar algemene verhalen over Brussel als 'gangland'. Van Hellemont concludeert dat journalisten in feite hetzelfde doen als jongens op de straathoek: ze bouwen verhalen en vermengen fictie en realiteit.

In het laatste hoofdstuk brengt Van Hellemont de verschillende spelers bij elkaar en laat zien hoe ze gebruik maken van elkaars verhalen zonder kritisch te kijken naar wat 'waar' is en wat niet. Ze construeren samen de mythe. Zonder het spel, dat voor de spelers om uiteenlopende redenen aantrekkelijk en verleidelijk is, kunnen gangs niet bestaan. Een ander belangrijk punt dat Van Hellemont maakt, is dat leden van gangs (ofwel gang gamers) soms zelf bepalen om mee te doen aan het spel, maar er soms ook onbewust en ongewild worden ingezogen van buitenaf, door het etiket dat door de overheid of media op hen of hun vriendengroep wordt geplakt.

De kracht van The gang game ligt in het feit dat het verschillende actoren belicht. Het analyseert niet alleen de rol van de 'klassieke' jongens op de straathoek, maar ook die van beleidsmakers, politieagenten, politici, journalisten en het grotere publiek. Van Hellemont beargumenteert overtuigend dat juist in de interactie van die verschillende spelers de mythe ontstaat en in stand wordt gehouden. Een ander sterk en interessant punt van het proefschrift is dat het laat zien hoe het spel tegelijkertijd op verschillende borden wordt gespeeld: online en offline. Het claimen van ruimte, het opbouwen van een reputatie, het uitdagen, provoceren en bespotten van anderen vinden zowel plaats in face-to-face ontmoetingen als op blogs, YouTube en Facebook. De analyse van Van Hellemont heeft daarmee een indrukwekkend reikwijdte. De keerzijde van die brede opzet is dat ze onderweg ook veel zijwegen inslaat, nieuwe vragen stelt en extra classificaties en concepten introduceert. Af en toe lijkt het alsof ze daarbij sterk afgeleid wordt door de grote hoeveelheid empirische data. Een fijnmaziger en eenduidiger conceptueel kader had nog meer houvast en inzicht kunnen geven in de spelregels van The gang game. 
Een ander probleem is dat de analyse van Van Hellemont vaak gericht lijkt te zijn op het ontleden van het constructieproces van mythes, maar soms ook een ander doel lijkt na te streven: het ontmaskeren of doorprikken van die mythes. Het zijn twee verschillende uitgangspunten: wil Van Hellemont inzicht geven in de totstandkoming van verhalen waarin fictie en 'realiteit' worden vermengd, of juist de 'realiteit' over Brusselse gangs presenteren? Dat laatste komt vooral naar voren in de hoofdstukken waarin zij scherpe kritiek levert op beleidsmakers, politieagenten en sommige journalisten die niet de 'waarheid' presenteren rondom gangs. Het roept direct ook de vraag op hoe die 'waarheid' gedefinieerd moet worden en wie die bepaalt, zeker gezien haar sterk constructivistische en interpretatieve benadering. Opvallend is ook dat de fictieve elementen in de mythevorming van jongens op straat niet bekritiseerd worden, maar vooral omschreven als een uiting van creativiteit, artistieke activiteit en straatpoëzie. De fictieve elementen bieden jonge Congolese mannen spanning en plezier, het is een uitvlucht voor de realiteit van een doorgaans saai alledaags bestaan. De selectieve kritiek op fictieve elementen is begrijpelijk, omdat de Congolese jongens een ondergeschikte machtspositie hebben in het spel. Zij ondervinden immers vooral de consequenties van de mythes: de dagelijkse hinder van de stereotiepe etiketten die ze krijgen opgeplakt en de uitsluiting die daarmee gepaard gaat. Tegelijkertijd roept het wel de vraag op in hoeverre Van Hellemont zelf als wetenschapper onderdeel is van het 'spel'. In het methodische hoofdstuk en aan het einde van het proefschrift stipt ze kwesties rondom positionality wel kort aan. Ze stelt dat zij als wetenschapper óók gefascineerd is door het spel en zich ertoe aangetrokken voelt. Het was echter interessant geweest als ze hier nog dieper op had gereflecteerd. Niet zozeer op de nauwe verbondenheid met haar onderwerp en haar respondenten (inherent aan goed etnografisch onderzoek), maar vooral op haar eigen positie in The gang game en de implicaties daarvan. Staat ze als wetenschapper buiten de lijnen van dat spel en biedt zij slechts een handleiding van hoe het gespeeld wordt? Of is zij naast journalisten, politieagenten, politici, beleidsmakers en jongens op de straathoek innig verweven in het spel dat ze onderzoekt? En zo ja, welke rol speelt zij dan precies en hoe verhoudt die zich tot de rollen die door andere betrokkenen worden gespeeld?

Tot besluit, The gang game is een zeer relevant en inspirerend proefschrift, dat met passie en op toegankelijke wijze is geschreven. Het zet aan tot kritische reflectie over hoe we onderzoek moeten doen naar gangs, hoe we erover schrijven, hoe we beleid maken, en hoe we omgaan met de verhalen over gangs in de media. Het geeft inzicht in het spel van mythevorming en onze eigen rol in de totstandkoming daarvan.

\section{Literatuur}

Katz, J. (1988). Seductions of crime: moral and sensual attractions in doing evil. New York: Basic Books.

Katz, J. \& Jackson-Jacobs, C. (2004). The criminologists' gang. In: C. Sumner (ed.). Blackwell companion to criminology. London: Blackwell Publishers, 91-124. 
The gang game: the myth and seduction of gangs

Thrasher, F.M. (1927). The gang: a study of 1313 gangs in Chicago. Chicago, IL: University of Chicago Press. 